P-ISSN: 2548-5962 $\begin{aligned} & \text { DIRECTORY OF } \\ & \text { OPEN ACCESS } \\ & \text { JOURNALS }\end{aligned}$
$\begin{aligned} & \text { E-ISSN: 2548-981X } \\ & \text { https://ojs.unud.ac.id/index.php/jbn }\end{aligned}$

\title{
Pembedahan Kanker di Masa Pandemi COVID-19
}

\section{Wayan Sudarsa}

Divisi Bedah Onkologi, Departemen Ilmu Bedah, Fakultas Kedokteran Universitas Udayana, RSUP Sanglah Denpasar.

*Penulis korespondensi: sudarsa1510@yahoo.com.

\section{DOI: https://doi.org/10.24843/JBN.2020.v04.is01.p01}

Corona Virus Disease 2019 (COVID-19), atau yang dikenal juga dengan Severe Acute Respiratory Syndrome Coronavirus 2 (SARS-CoV-2), ditemukan pertama di Wuhan pada Desember 2019, yang menyebabkan kematian sebesar 12.784 penderita, dan telah menyebar ke beberapa negara. ${ }^{1}$ Penyebaran COVID-19 pada tahun 2020 sebesar lebih dari 450.000 kasus di seluruh dunia. ${ }^{2}$ Vaksin dan terapi definitif yang memuaskan masih belum tersedia, sehingga World Health Organization (WHO) merekomendasikan social distancing untuk menekan penyebaran COVID-19. ${ }^{2}$ Dampak dari pandemi ini menimbulkan kepanikan bagi seluruh lapisan masyarakat bahkan tenaga medis, karena tidak sedikit tenaga medis yang meninggal dunia akibat tertular COVID-19. ${ }^{3}$ Selain itu keterbatasan alat pelindung diri (APD), kapasitas ruang perawatan dan peralatan medis yang terbatas serta jumlah penderita COVID-19 yang semakin meningkat menjadi perhatian khusus bagi tenaga medis. ${ }^{3}$

Di Wuhan, China, evaluasi pada 34 pasien yang menjalani operasi elektif di empat rumah sakit pada masa inkubasi (1 - 5 Januari 2020) mengalami pneumonia dan terkonfirmasi COVID-19. Didapatkan 15 pasien $(44,1 \%)$ memerlukan perawatan ICU dengan mortalitas $20,5 \% .^{4}$

Penderita usia tua dan atau dengan komorbid penyakit kronik yang terinfeksi
COVID-19 memiliki prognosis yang buruk. ${ }^{5}$ Pada penderita kanker yang terinfeksi oleh COVID-19, maka sangat dibutuhkan peralatan proteksi yang adekuat bagi ahli bedah onkologi dan alat ventilator yang memadai. American Cancer Society mengumumkan terdapat lebih dari 5.000 kasus kanker yang terinfeksi COVID-19. ${ }^{5}$ Keadaan ini membuat ahli bedah onkologi harus mampu menentukan "timing” yang tepat untuk dapat melakukan prosedur diagnostik, terapi bedah secara "elective" atau tindakan segera "urgency", dan follow up penderita yang sesuai secara tepat. ${ }^{5}$

Berdasarkan laporan penelitian di China, penderita kanker dengan COVID-19 memiliki angka morbiditas yang tinggi, termasuk kebutuhan ventilator dengan angka kematian yang tinggi (hazard ratio, 3,56 [95\% CI, 1,65 - 7,69]. ${ }^{6}$ Studi lain di China menunjukkan pasien kanker di pusat epidemik virus memiliki risiko infeksi 2,31 lebih besar $[95 \%$ CI $1,89 \quad-\quad 3,02]$ dibandingkan pasien lain. ${ }^{7}$

Mengingat tingginya angka penyebaran COVID-19 dan tingginya risiko menginfeksi tenaga medis setelah melakukan tindakan pembedahan, kemoterapi atau radiasi, maka seorang ahli bedah onkologi diharapkan dapat menentukan benefit dan risk dalam penanganan penderita kanker di masa COVID-19, sehingga penting untuk menentukan tindakan elective atau urgency. ${ }^{8}$ 
Pada Tabel 1 perlu diperhatikan contoh pada kanker hepato-pankreato-bilier, apabila kasus kanker payudara (early stage) yang terjadi respon setelah pemberian kemoterapi memerlukan terapi neoadjuvan adalah kasus neoadjuvan maka tindakan pembedahan yang dapat ditunda sebagai "delaying dapat ditunda. ${ }^{11}$ Rekomendasi dari American surgery". 8-10 Society of Surgical Oncology College of Surgeons yaitu keputusan untuk (SSO) merekomendasikan kanker saluran melakukan tindakan bedah di masa COVIDcerna bagian atas (SCBA) cenderung 19 harus berdasarkan ketersediaan ahli memerlukan tindakan urgency, terutama yang anestesiologi, perawat, dan fasilitas kesehatan mengalami obstruktif dan perdarahan aktif. ${ }^{11}$ yang memadai dalam menghadapi Sedangkan kanker pada bagian kepala dan kemungkinan penularan COVID-19, selain leher dapat ditunda selama $4-8$ minggu itu juga memikirkan komplikasi dan masa selama pandemi COVID-19. Demikian juga perawatan setelah pembedahan. ${ }^{12}$

Tabel 1. Pertimbangan Tindakan Pembedahan Berdasarkan Risiko., ${ }^{8,9}$

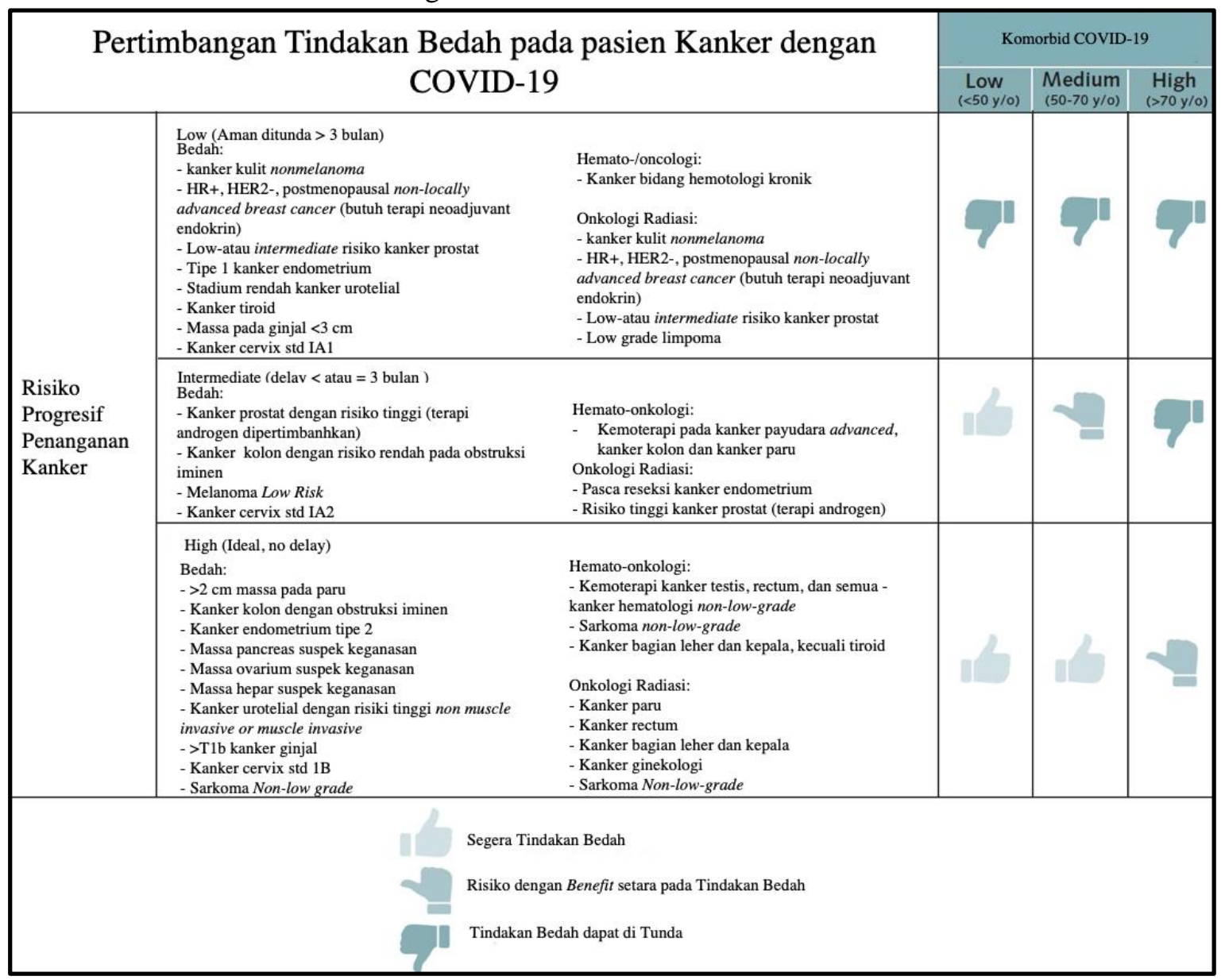

Pertimbangan terapi adjuvan bagi Selain pertimbangan secara klinis dan penderita tumor solid dengan kemoterapi hasil pemeriksaan penunjang, terdapat yang sudah lengkap atau bahkan yang baru beberapa pertimbangan yang perlu memulai kemoterapi, dengan hasil diperhatikan seperti ketersediaan ruang pemeriksaan COVID-19 positif, merupakan perawatan intensif (RTI), perawatan isolasi langkah terapi pertama yang tepat dengan yang memadai, ventilator, ketersediaan berbagai pertimbangan secara rasional. ${ }^{13} \quad$ cadangan darah untuk transfusi, dan tenaga 
medis yang ahli terutama bidang onkologi di masa COVID-19.

Meskipun penderita kanker umumnya dapat dilakukan pembedahan yang bersifat elective, namun edukasi kepada penderita dan keluarga merupakan cara yang baik di masa COVID-19 ini. Pemeriksaan yang standard seperti pemeriksaan darah, imaging, dan kontrol lanjutan di poli rawat jalan pun dapat ditunda, dengan tujuan semua ini untuk menurunkan angka penularan COVID-19 terutama kepada ahli bedah onkologi. ${ }^{3}$

Secara ringkas, perawatan penderita kanker di masa COVID-19 ini, telah mengubah paradigma antara penderita dan tenaga medis terutama ahli bedah onkologi, untuk bersama-sama melawan COVID-19, maka dari itu diperlukan komunikasi yang baik antara dokter dengan penderita, edukasi penyakit dan tindakan prosedur yang dapat ditunda atau segera dikerjakan berdasarkan guideline terkini, dan persiapan ketersediaan sumber daya yang ada merupakan pertimbangan yang penting, untuk menekan penyebaran COVID-19 bagi tenaga medis terutama ahli bedah onkologi di Indonesia.

\section{DAFTAR PUSTAKA}

1. Shankar A, Saini D, Roy S, dkk. Cancer care delivery challenges amidst coronavirus disease-19 (COVID-) outbreak: specific precautions for cancer patients and cancer care providers to prevent spread. Asian Pac J Cancer Prev. 2020;21:569-73.

2. Ferguson NM, Laydon D, Nedjati-Gilani G. Report 9: impact of nonpharmaceutical interventions (NPIs) to reduce COVID-19 mortality and healthcare demand. Imperial College London. [serial online] 16 Maret 2020 [diakses 01 April 2020]. Diunduh dari: www.imperial.ac.uk/mrc-global- infectious-disease-analysis/news--wuhancoronavirus pada 01 April 2020.

3. Al-Shamsi H, Alhazzani W, Alhuraiji A, dkk. A Practical Approach to the Management of Cancer Patients During the Novel Coronavirus Disease 2019 (COVID-19) Pandemic: An International Collaborative Group. Oncologist. 2020.

4. Lei S, Jiang F, Su W, dkk. Clinical characteristics and outcomes of patients undergoing surgeries during the incubation period of COVID-19 infection. EClinicalMedicine. 2020.

5. Chen N, Zhou M, Dong X. Epidemiological and clinical characteristics of 99 cases of 2019 novel coronavirus pneumonia in Wuhan, China: a descriptive study. Lancet. 2020;395:507-13.

6. Liang W, Guan W, Chen R. Cancer patients in SARS-CoV-2 infection: a nationwide analysis in China. Lancet Oncol. 2020;21:335-37.

7. Yu J, Ouyang W, Chua MLK, Xie C. SARS-CoV-2 Transmission in Patients With Cancer at a Tertiary Care Hospital in Wuhan, China. JAMA Oncol. 2020.

8. Kutikov A, Weinberg DS, Edelman MJ, dkk. A war on two fronts: cancer care in the time of COVID-19. Ann Intern Med. 2020.

9. American College of Surgeons. COVID19: Elective Case Triage Guidelines for Surgical Care. [serial online] 24 Maret 2020 [diakses 01 April 2020] Diunduh dari: https://www.facs.org/covid19/clinical-guidance/elective-case.

10. American Society of Clinical Oncology. COVID-19 Patient Care Information. [serial online] 02 April 2020 [diakses 02 April 2020]. Diunduh dari: https://www.asco.org/ascocoronavirusinformation/care-individuals-cancerduring-covid-19. 
11. Bartlett DL, Howe JR. Cancer Surgeries in the Time of COVID-19: A Message from the SSO President and PresidentElect. Chicago: Society of Surgica Oncology; 2020.

12. American College of Surgeons. Create a Surgical Review Committee for COVID19-Related Surgical Triage Decision Making. [serial online] 24 Maret 2020 [diakses 01 April 2020]. Diunduh dari: https://www.facs.org/covid-19/clinicalguidance/review-committee.

13. Ueda M, Martins R, Hendrie PC, dkk. Managing cancer care during the COVID19 pandemic: agility and collaboration toward a common goal. J Natl Compr Canc Netw. 2020;18:1-4. 